\title{
Vitae
}

33 (2018) $155-178$

Ks. Tomasz Bąk

Katolicki Uniwersytet Lubelski Jana Pawła II, Lublin

tomciobak@gmail.com, ORCID: 0000-0003-0328-0282

\section{Gniew Jezusa pod Cezareą Filipową. STUdium EgZegetyCZne MK 8,31-33}

The Wrath of Jesus at Caesarea Philippi. An Exegetical Study of Mk 8:31-33

Perykopa Mk 8,31-33 bez wątpienia należy do najtrudniejszych fragmentów Ewangelii. Do Apostoła Piotra, który wcześniej wyznał swoją wiarę w Jezusa jako Mesjasza (w. 29), odnoszą się słowa: „Zejdź mi z oczu szatanie" (w. 33). Niniejszy artykuł próbuje pokazać, iż Jezus w swojej naganie nie zamierza odrzucać Piotra, nawet jeśli czasownik

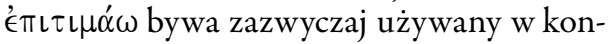
tekście wyrzucania złych duchów. Celem wydarzenia w Cezarei Filipowej jest ponowne wezwanie Apostoła, tym razem do bezwarunkowego pójścia za Jezusem. Jezusowe słowa:

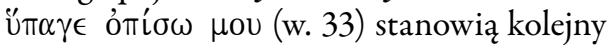
etap powołania Piotra, opisanego już na początku $(1,16-18)$ i na końcu $(16,7)$ Ewangelii według św. Marka. 
The pericope of Mk 8:31-33 undoubtedly Jesus' rebuke; ranks among the most complex fragments in the entire Gospel. The Apostle Peter, who had already confessed his faith in Jesus as the Messiah (v. 29), is referred to with the followMark 8:31-33; Peter's rebuke; Peter's calling; ing words: "Get behind Me, Satan" (v. 33). This article attempts to show that Jesus, in his rebuke of his apostle (even though the verb $\epsilon \pi \iota \tau \mu \alpha \dot{\alpha} \omega$ is consistently used in the Gospel to describe the casting out of unclean spirits) does not intend to condemn or reject Peter. Instead, the meaning behind the scene that played out in Caesarea Philippi is yet another call for Peter to follow Jesus unconditionally.

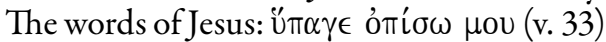
bring to mind Peter's calling, described both at the beginning (1:16-18) and at the end (16:7) of the Gospel of Mark.

Satan

Jedną z podstawowych kwestii poruszanych w Ewangelii według św. Marka jest udzielenie odpowiedzi na pytanie: kim jest Jezus? Już w pierwszym wersecie czytamy: „Początek Ewangelii Jezusa Chrystusa, Syna Bożego”. A zatem Jezus jest Chrystusem, Synem Bożym. Podobne stwierdzenie znajduje się na końcu dzieła, kiedy to po ukrzyżowaniu setnik stwierdza: „Istotnie, ten człowiek był Synem Bożym” (Mk 15,39). Tożsamość Jezusa Chrystusa, Syna Bożego, stanowi zatem swoistą klamrę opasującą całe dzieło ewangelisty Marka. Kwestia pytania, kim jest Jezus, pojawia się również w bardzo wyraźnej formie w samym centrum Ewangelii. W okolicy Cezarei Filipowej Jezus stawia bowiem swoim uczniom dwa bardzo ważne pytania: „za kogo uważają Mnie ludzie?” oraz „za kogo wy Mnie uważacie” (Mk 8,27.29). Odpowiedź na pierwsze pytanie nie stanowi zbyt wielkiego wyzwania. 
Uczniowie referują opinie odnoszące się do powszechnego traktowania Jezusa jako Jana Chrzciciela, Eliasza lub jednego z proroków (Mk 8,28). Znacznie trudniej natomiast jest poradzić sobie z kwestią osobistego postrzegania Jezusa. Odpowiedzi udziela Piotr: „Ty jesteś Mesjasz” (Mk 8,29). W Ewangelii według św. Mateusza spotyka go za to wielka pochwała: „Błogosławiony jesteś, Szymonie, synu Jony” (Mt 16,17). Piotr udziela poprawnej odpowiedzi: Jezus jest mesjaszem. Kiedy jednak ten sam Mesjasz zaczyna mówić o swoim losie, że „Syn Człowieczy musi wiele wycierpieć, że będzie odrzucony przez starszych, arcykapłanów i uczonych w Piśmie; że zostanie zabity, ale po trzech dniach zmartwychwstanie" (Mk 8,31), Piotr bierze Go na bok i zaczyna upominać. Wywołuje to bardzo ostrą reakcję ze strony Jezusa: „Zejdź mi z oczu, szatanie, bo nie myślisz po Bożemu, lecz po ludzku" (Mk 8,33). Co znaczą te słowa i dlaczego reakcja Jezusa jest tak gwałtowna? Czy Piotr rzeczywiście zasłużył na gniew swego Mistrza? Jakie jest znaczenie perykopy o gniewie Jezusa w kontekście całego dzieła Markowego?

Komentarze do Ewangelii według św. Marka podkreślają, iż scena pod Cezareą Filipową, jako „wzajemne upomnienie Jezusa i Piotra"1 należy do najbardziej bolesnych w całej Ewangelii ${ }^{2}$. Zazwyczaj zwracają uwagę, iż Piotr, który powinien znać teksty Starego Testamentu o cierpiącym słudze Jahwe ${ }^{3}$, został skarcony ze względu na błędną koncepcję Mesjasza ${ }^{4}$, a także z tego powodu, iż jego myślenie nie było skupione na sprawach Bożych ${ }^{5}$. W niniejszym artykule posta-

1 „The mutual rebuke by Peter and Jesus”. Geddert, Mark, 203.

2 Np. van Iersel, Mark, 285.

3 Temat cierpiącego człowieka sprawiedliwego był obecny chociażby w psalmach, a tym bardziej Piotr powinien znać chociażby Iz 53 mówiący o cierpiącym słudze Jahwe (zob. Hooker, Gospel, 204). O Jezusowym cierpieniu i jego niezrozumieniu ze strony najbliższych zob. Dinkler, „Suffering”, 319-330.

4 Zob. np. Geddert, Mark, 203.

5 Zob. np. Collins, Mark, 406. 
ramy się zwrócić uwagę na znaczenie Jezusowego oburzenia w kontekście formacji uczniów, którym w Ewangelii według św. Marka zostało poświęcone tak wiele uwagi ${ }^{6}$.

Analiza perykopy Mk 8,27-33, ze szczególnym zwróceniem uwagi na ostatnie wersety, zostanie przeprowadzona zgodnie z założeniami metody synchronicznej. W pierwszej kolejności zostanie dokonana delimitacja, a następnie, zgodnie z założeniami krytyki tekstu, ustalenie greckiego brzmienia interesującego nas fragmentu ${ }^{7}$. Kolejnym krokiem będzie ustalenie struktury tekstu i porównanie synoptyczne z pozostałymi Ewangeliami, a następnie wyjaśnienie egzegetyczne interesujących nas wersetów i w końcu znaczenie wybranej perykopy w kontekście całości Ewangelii według św. Marka.

\section{Delimitacja}

Jeżeli podstawowymi kryteriami służącymi do określenia początku i końca danej perykopy są wyznaczniki czasu, miejsca, osób i tematyki ${ }^{8}$, to bez wątpienia można stwierdzić, iż fragment Mk 8,27-33 stanowi samodzielną jednostkę w Ewangelii. Jezus udaje się „,do wiosek pod Cezareą Filipową”, a więc następuje zmiana miejsca: z Betsaidy Jezus wędruje na północ. Zmieniają się również osoby: nie ma już niewidomego i tych, którzy mu towarzyszyli (Mk 8,22-26). Jezus pozostaje sam ze swoimi uczniami. Zmienia się również tematyka narracji: po uzdrowieniu niewidomego przychodzi czas na pytanie o tożsamość Jezusa. Wszystkie te argumenty przemawiają za tym, żeby w Mk 8,27 dopatrywać się początku nowej pery-

$6 \quad$ Zob. np. Mk 1,16-20; 2,13-17; 3,13-19; 4,10-13; 6,7-13.30-52; 8,19.14-21.27-33; 9,2-13.33-41; 10,13-16.23-45; 11,20-26; 13,5-13; $14,10-42.66-72 ; 16,7$.

7 W analizie synchronicznej nie zajmujemy się kwestiami związanymi $\mathrm{z}$ debatowaniem na temat autentyczności naszej perykopy. Można się z nimi zapoznać np. w artykule: Zolondek, „Authenticity”, 237-253.

8 Por. Egger, Metodologia, 53-57. 
kopy. Zmiana osób w 8,34 (Jezus przywołuje tłum) i nieco odmienna tematyka (Jezus mówi o warunkach naśladowania Go) sprawiają, iż wersety 8,27-33 mogą być traktowane jako odrębna perykopa ewangeliczna ${ }^{9}$. W jej obrębie, od 8,31 pojawia się nowa tematyka: "[Jezus] zaczął ich pouczać, że Syn Człowieczy musi wiele wycierpieć”. Wersety 8,31-33 stanowią zatem podjednostkę sceny z okolic Cezarei Filipowej ${ }^{10}$ i staną się dominującym przedmiotem naszej analizy.

\section{Ustalenie TeKstu}

Analiza aparatu krytycznego pokazuje, iż w zasadzie wszystkie rękopisy przekazują tekst w jednakowej formie. Drobną zmianę możemy zaobserwować w 8,28 , gdzie w miejscu:

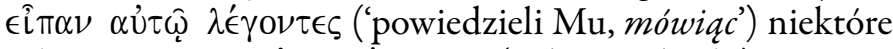
rękopisy czytają: $\alpha \pi \epsilon \kappa \rho i ́ \theta \eta \sigma \alpha \nu$ ('odpowiedzieli'). Zmiana ta nie wpływa jednak na rozumienie tekstu. Niektóre ma-

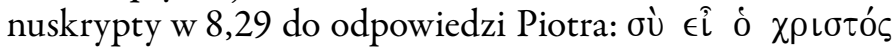

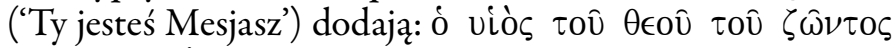
('Syn Boga Żywego'), co stanowi oczywisty wpływ tekstów

9 Wśród egzegetów można spotkać opinie, sugerujące zakończenie perykopy w 8,38 albo nawet w 9,1 . Należą one jednak do mniejszości. Różne stanowiska biblistów w kwestii podziału sceny pod Cezareą Filipową zostały bardzo dokładnie przedstawione we współczesnym opracowaniu P. Mascilongo (Mascilongo, „Ma voi, chi dite”, 15-21).

10 Taki podział można zauważyć chociażby w klasycznym dziele Taylora, poświęconym Ewangelii według św. Marka. Analizując wersety Mk 8,27-33, autor nadaje im dwuczłonowy tytul: „The confession of Peter and the first prophecy of the Passion" (Taylor, The Gospel, 374), sugerując tym samym możliwość podziału perykopy na dwie narracyjne podjednostki. Werset 31 może stanowić początek nowej sekcji: „It is possible to regard viii.31 as the beginning of a narrative, or indeed a new section" (Taylor, The Gospel, 377). Podobne stwierdzenie znajdujemy również u Mascilongo: „In 8,31 inizia un'unità narrativa distinta ma strettamente legata alla precedente" (Mascilongo, „Ma voi, chi dite”, 286). 
synoptycznych, szczególnie Ewangelii według św. Mateusza (Mt 16,16, por. Łk 9,20). Poza tymi dwiema różnicami tekst perykopy jest w zasadzie wszędzie jednorodny, co sprawia, iż do dalszych analiz można bez wahania przyjąć wersję, która znajduje się w najnowszym wydaniu Nestle-Aland. Większe zastrzeżenia może budzić tłumaczenie tego tekstu na język polski, szczególnie gdy bierzemy pod uwagę interesujący nas fragment wersetu 8,33: „Zejdź mi z oczu szatanie”11. Przekład dokonany w ten sposób nie jest do końca poprawny, co zostanie ukazane w dalszej części artykułu.

\section{Struktura tekstu}

Perykopa Mk 8,27-33 pod względem układu treści nie jest zbyt skomplikowana. Jak już zostało wspomniane, można w niej wyróżnić dwie podjednostki określane jako: wyznanie wiary Piotra (w. 27-30) oraz pierwsza zapowiedź męki (w. 31-33). Schematycznie można ją przedstawić w następujący sposób:

a) wyznanie wiary (w. 27-30):

- informacja geograficzna (w. 27a);

- pytanie Jezusa (w. 27b);

- odpowiedź uczniów (w. 28);

- pytanie Jezusa (w. 29a);

- odpowiedź Piotra (w. 29b);

- nakaz milczenia (w. 30);

b) zapowiedź męki (w. 31-33):

- nauka o losie Syna Człowieczego (w. 31-32a);

- upomnienie ze strony Piotra (w. 32b);

- reakcja Jezusa (w. 33).

Piotrowe upomnienie i „nerwowa” reakcja Jezusa, czyli dwa ostatnie wersety, będą stanowić przedmiot naszego największego zainteresowania.

11 Biblia Paulistów tłumaczy w podobny sposób: „Szatanie, odejdź ode Mnie!". 


\section{Porównanie SyNOPTYCZne}

Zwrócimy w tym miejscu uwagę jedynie na końcową część perykopy, która będzie mieć największy związek z naszymi dalszymi analizami. Dokonując porównania pomiędzy synoptykami, należy przede wszystkim zauważyć, iż w Ewangelii według św. Łukasza (Łk 9,18-22) nie występują kluczowe dla nas dwa ostatnie wersety. $U$ trzeciego ewangelisty, podkreślającego miłosierne oblicze Boga, całkowicie pominięty zostaje „niewygodny” dla jego teologii epizod upominania Jezusa przez Piotra. Nie znajdziemy też w jego dziele ostrych słów, jakie Jezus wypowiedział do najważniejszego ze swoich Apostołów. W porównaniu synoptycznym skazani więc jesteśmy jedynie na konfrontację Ewangelisty Marka z Mateuszem. Tabelarycznie interesujące nas dwa końcowe wersety prezentują się w następujący sposób:

\begin{tabular}{|c|c|}
\hline Mk 8,32-33 & Mt $16,22-23$ \\
\hline 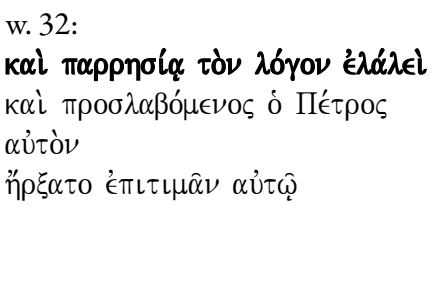 & 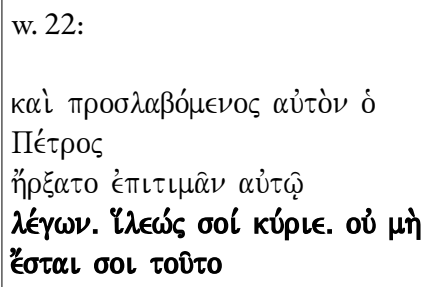 \\
\hline 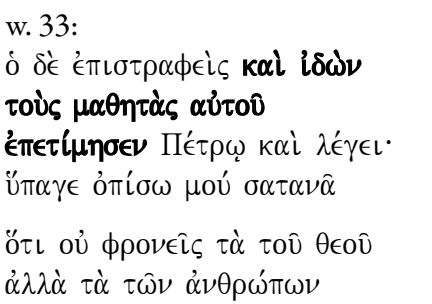 & 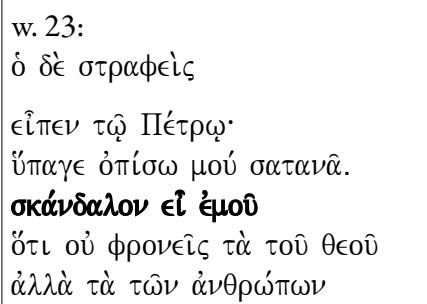 \\
\hline
\end{tabular}

Jak wynika z tabeli, zanim Piotr wziął Jezusa na bok, ewangelista Marek zaznacza, iż Jezus „mówił zupełnie otwarcie te słowa" (w. 32a), co odnosi się oczywiście do zapo- 
wiedzi losu, jaki Go spotka. Mateusz natomiast, bez „zbędnego” wprowadzenia, od razu zaznacza, iż „Piotr wziął Go na bok i począł robić Mu wyrzuty" (w. 22). W od różnieniu od Marka podaje jednak słowa, z jakimi Piotr zwrócił się do Jezusa: „Panie, niech Cię Bóg broni! Nie przyjdzie to nigdy na Ciebie" (w. 22). Podobnie, w kolejnym wersecie, tylko Mateusz wprowadza do wypowiedzi Jezusa słowa skierowane do Piotra: ,jesteś Mi zawadą” (w. 23).

Widać wyraźnie, iż wypowiedzi Piotra czy Jezusa w Ewangelii Marka są nieco krótsze niż u Mateusza. Marek dodaje jednak pewien szczegół w swojej narracji. O ile u Mateusza słowa krytyki odnoszą się do samego Piotra, o tyle w Ewangelii Marka są one skierowane do wszystkich uczniów: Jezus upomniał Piotra "patrząc na swoich uczniów" (w. 33). Warto odnotować jeszcze jedną zmianę, która w dalszej części artykułu okaże się dość istotna, a mianowicie tam, gdzie u Mateusza Jezus „rzekł Piotrowi” (єi $\pi \in \nu \tau \hat{\varphi}$ $\Pi \epsilon \in(\rho)$, u Marka zastosowany został inny czasownik: Jezus

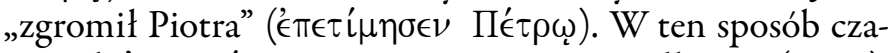

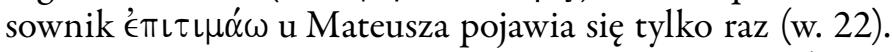
U Marka natomiast zostaje powtórzony dwukrotnie (w. 32 i 33): najpierw Piotr „upomina” Jezusa, a później Jezus „gromi” Piotra. W dalszej części zobaczymy, iż takie powtórzenie nie jest przypadkowe.

\section{Analiza egzegetyczna}

W wyjaśnieniu egzegetycznym perykopy Mk 8,27-33 nasza uwaga zostanie skoncentrowana przede wszystkim na dwóch końcowych wersetach. Analiza wcześniejszych wierszy zostanie dokonana o tyle, o ile przyczyni się do lepszego zrozumienia wersetów końcowych.

$\mathrm{Na}$ początku perykopy, podając informację topograficzną o Cezarei Filipowej, Marek podkreśla, iż Jezus udał się tam „ze swoimi uczniami” (w. 27). Stosuje tutaj wyrażenie: 


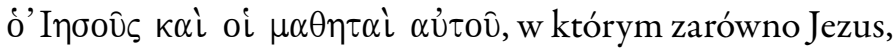
jak i Jego uczniowie podani zostają w nominativie, stając się podmiotem zdania. Jest to jedyne miejsce w całej Ewangelii według św. Marka, gdzie spotykamy to wyrażenie. Polskie tłumaczenie BT: „Jezus udał się ze swoimi uczniami” nie do końca oddaje specyfikę tekstu greckiego. Lepszym, bardziej dosłownym przekładem byłoby: "Jezus i Jego uczniowie”. Warty podkreślenia jest również czasownik '€ $\xi \hat{\eta} \lambda \theta \in \nu$. Tam, gdzie oczekiwalibyśmy formy $\epsilon^{\prime} \xi \hat{\eta} \lambda \theta o \nu$, pojawia się czasownik w liczbie pojedynczej ${ }^{12}$. Jezus i Jego uczniowie stanowią zatem jedność ${ }^{13}$. „Wyszedł Jezus i Jego uczniowie” to najbardziej dosłowne tłumaczenie początkowej części wersetu 8,27 , a zarazem początku całej perykopy. Autor dąży tu do szczególnego podkreślenia bliskości Jezusa i Jego uczniów.

Ewangelista Marek, jako jedyny z synoptyków, zwraca również uwagę na fakt, iż Jezus zadaje swoim uczniom pytanie: $\epsilon \nu$ 行 $\delta \delta \omega ̣$ ('w drodze'). Według tradycyjnie przyjętego podziału to właśnie w Mk 8,27 rozpoczyna się druga, centralna część Ewangelii Markowej ${ }^{14}$. Jest ona poświęcona drodze do Jerozolimy i koncentruje się w szczególny sposób na relacji między Jezusem i Jego uczniami. Próbuje dać odpowiedź na pytanie: kim jest, czy raczej, kim powinien być uczeń Jezusa? Sekcja drogi do Jerozolimy zakończy się w ostatnim wersecie dziesiątego rozdziału. Mk 11,1 to już początek ostatniej, trzeciej części Ewangelii, opisującej wydarzenia paschalne w świętym mieście. Na początku środkowej

12 W wersetach mówiących o przemieszczaniu się Jezusa z uczniami Marek najczęściej stosuje liczbę mnogą. Np. w 9,30 spotykamy formę participium: $\mathfrak{\epsilon}^{\prime} \xi \in \lambda \theta o ́ v \tau \epsilon \zeta$, bez jasnego sprecyzowania podmiotu, w 9,33 tryb oznajmujący: ท̂̉ $\theta$ ov (również z podmiotem domyślnym),

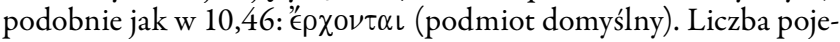
dyncza na początku naszej perykopy jest dla Marka czymś nietypowym i zapewne nie została użyta przypadkowo.

13 Zob. Haręzga, Jezus i Jego uczniowie, 202.

14 Wyodrębnianie Mk 8,27-10,52 jako drogi Jezusa i Jego uczniów do Jerozolimy jest powszechnie uznawane wśród egzegetów (zob. np. Malina, Ewangelia, 46-47). 
sekcji, w Mk 8,27, ewangelista podkreśla zatem szczególną bliskość Jezusa i Jego uczniów oraz zwraca uwagę, iż znajdują się oni „w drodze” do Jerozolimy.

Jezus pyta najpierw o opinie ludzi na temat swojej osoby. Uczniowie referują odpowiedzi innych, postrzegających Jezusa jako Jana Chrzciciela, Eliasza czy jednego z proroków. Przytaczają w tym miejscu powszechne opinie, które krążyły na temat ich Mistrza. Wystarczy przywołać chociażby perykopę Mk 6,14-16, kiedy to w kontekście ścięcia Jana Chrzciciela Herod traktuje Jezusa jako zmartwychwstałego Jana (w. 14), a inni postrzegają Go jako Eliasza lub jednego z dawnych proroków (w. 15). W odpowiedzi udzielonej Jezusowi przez uczniów nie ma więc niczego nadzwyczajnego. Referują to, co powszechnie było mówione o Jezusie.

Po zainteresowaniu opinią ludzi pada jednak ze strony Jezusa kolejne, znacznie trudniejsze pytanie: „A wy za kogo Mnie uważacie” (Mk 8,29). Język grecki zdradza tu pewną atmosferę zaskoczenia. Uczniowie mogli nie spodziewać się takiego bezpośredniego zwrotu. W wersecie 8,27 pierwsze pytanie Jezusa rozpoczyna się w bardzo naturalny, ,"spokojny”

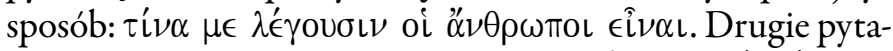

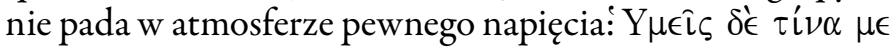

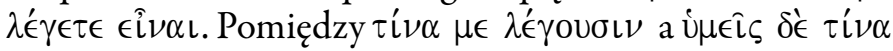
daje się zauważyć pewną grę językową, dzięki której Marek w mistrzowski sposób oddaje klimat zaskoczenia i napięcia, a tym samym podkreśla wagę i znaczenie stawianego przez Jezusa pytania ${ }^{15}$. Opinia ludzi Jezusowi nie wystarczy. Pada pytanie o osobistą opinię uczniów. Oni są kimś innym niż zwykli przeciętni ludzie. Od nich wymaga się czegoś więcej. Są z Jezusem od momentu powołania (1,16-20). Jezus wyjaśnia im kwestie, które dla zwykłych ludzi pozostają nieznane, co widać chociażby w interpretacji wygłaszanych przypowieści (np. 4,10-12).Z jednej strony mamy przekaz do ludzi: „w wielu takich przypowieściach głosił im naukę, o ile mogli [ją] 
rozumieć" (4,33), z drugiej zaś przesłanie kierowane do uczniów: „osobno zaś objaśniał wszystko swoim uczniom” (4,34).

Uczniowie są tymi, których Jezus wtajemnicza w swoją naukę i posłannictwo o wiele bardziej niż innych słuchaczy. W Ewangelii Marka znajdziemy opisy wielu scen „zarezerwowanych" tylko dla uczniów. Uciszenie burzy na jeziorze (4,35-41), kroczenie po wodzie (6,45-52), przygotowanie cudu rozmnożenia chlebów $(6,35-39 ; 8,1-5)$ to tylko niektóre przykłady wydarzeń rozgrywających się między Jezusem i Jego uczniami. Przebywanie z Mistrzem, słuchanie na osobności Jego słów, uczestniczenie w cudownych wydarzeniach, do których inni nie mieli dostępu, powinno wyrobić u uczniów nie tylko poczucie przynależności do Jezusa, ale też wzmocnić świadomość Jezusowej tożsamości. Uczeń po tym wszystkim, czego doświadczył, powinien wiedzieć, kim jest Jezus. Rzeczywistość okazuje się jednak inna. Po uciszeniu burzy na jeziorze pytają: „kim On jest właściwie?” $(4,41)$, po Jezusowym kroczeniu po wodzie „tym bardziej zdumieli się w duszy" (6,51), a po drugim rozmnożeniu chleba sam Jezus pyta: ,jeszcze nie pojmujecie i nie rozumiecie?” $(8,17)$, ,jeszcze nie rozumiecie?" $(8,21)$. Mógłby wydawać się pewnym paradoksem fakt, iż przebywanie z Jezusem nie wpływa na zwiększenie świadomości ucznia. Czytelnik Markowej Ewangelii odnosi wrażenie, że im dłużej z Nim przebywają, tym mniej rozumieją i tym więcej pytań rodzi się w ich umysłach. „A wy za kogo Mnie uważacie?” (Mk 8,29). Nie można rozpocząć bezpośredniego przygotowania do wejścia do Jerozolimy i uczestniczenia w wydarzeniach paschalnych bez świadomości, kim jest Jezus. Piotr odpowiada: „Ty je-

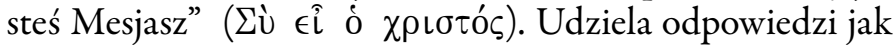
najbardziej poprawnej, wpisującej się w kluczowe punkty Markowej Ewangelii. Jak już zostało wspomniane, ChrystusaMesjasza-Namaszczonego ${ }^{16}$ spotykamy w pierwszym werse-

16 Gr. $\chi \rho\llcorner\sigma \tau o ́ \varsigma$ pochodzi od czasownika $\chi \rho i ́ \omega$ znaczącego tyle, co 'namaszczać' (zob. Popowski, Wielki Stownik, 657-661). 
cie: „Ewangelia Jezusa Chrystusa, Syna Bożego”. Tytuł ten pojawia się również pod koniec Ewangelii, w kontekście Jezusowej męki, w pytaniu zadanym przez najwyższego kapłana $(14,61)$ oraz w momencie wyszydzenia Jezusa na krzyżu $(15,32)$. Odpowiedź udzielona przez Piotra znajduje się w samym centrum Ewangelii $(8,29)$. Apostoł zna tożsamość Jezusa. Wie, że jest Mesjaszem. Ludzie mogą widzieć w Jezusie Jana Chrzciciela, który powstał z martwych, Eliasza, jednego z proroków. Dla ludzi Jezus może być „jedną z” wielkich postaci historycznych. Dla ucznia Jezus musi być kimś jedynym i niepowtarzalnym. Jezus jest „Mesjaszem”. Z taką świadomością uczniowie mogą rozpocząć drogę do Jerozolimy i bezpośrednie przygotowanie do wydarzeń paschalnych. Czy jednak uczniowie, w tym również Piotr, wiedzą, co to znaczy, że Jezus jest Mesjaszem?

Po Piotrowej deklaracji Jezus nakazuje uczniom zachowanie milczenia $(8,30)$ i zaczyna mówić o przyszłym losie Syna Człowieczego. Jezusa czeka cierpienie, odrzucenie ze strony wszystkich grup cieszących się w Izraelu największym autorytetem (starsi, arcykapłani, uczeni w Piśmie), śmierć i zmartwychwstanie. Taki los nie jest Jego wymystem, ale wpisuje się w odwieczny plan Boga, wyrażony w 8,31 słowem $\delta \in \hat{\imath}^{17}$. "Jest zatem konieczne/trzeba”, aby Syn Człowieczy cierpiał, umarł i zmartwychwstał. Jezus mówi te słowa „zupełnie ot-

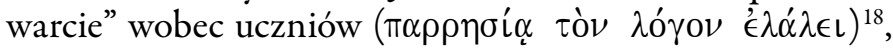
wprowadzając ich w największe tajemnice.

Jezusowa mowa o przyszłych wydarzeniach spotyka się ze zdecydowaną reakcją Piotra, która w pisuje się w kluczowy temat tego artykułu. Ewangelista Marek informuje czytel-

17 Zob. Haręzga, Jezus i Jego uczniowie, 212. Por. Maggioni, Il racconto, 125-127.

18 Termin $\pi \alpha \rho \rho \eta \sigma i \alpha$ powstał z połączenia dwóch rdzeni: $\pi \alpha \hat{\nu}$ ('wszyst-

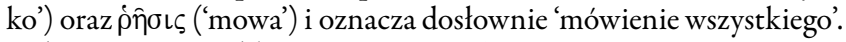
Zob. Haręzga, „Biblijna parrēsia”, 294-295, 299-300. Ks. Piwowar tłumaczy termin $\pi \alpha \rho \rho \eta \sigma i ́ \alpha$ jako „odważnie” (Piwowar, Sktadnia, 84), Hendriksen - „without any reservation” (Hendriksen, Exposition, 327). 
nika o dwóch czynnościach Apostoła. Po pierwsze, „Piotr wziął Go na bok" (Mk 8,32b). Język grecki używa tu terminu $\pi \rho 0 \sigma \lambda \alpha \beta$ ó $\mu \in \nu$ $\varsigma$ będącego aorystem użytym w formie participium. Służy on do zarysowania pewnego tła, na którym pojawi się czasownik w formie osobowej, stanowiący czynność główną. Dodatkowo widzimy, iż czasownik $\lambda \alpha \mu \beta \alpha \dot{\alpha} \nu 0 \mu \alpha \iota$ zo-

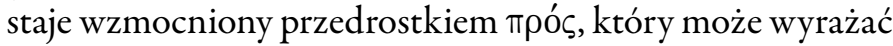
ruch ('do, ku, dla'), określać miejsce ('blisko, obok, przy') oraz wyrażać bliskość ('u kogoś, przy kimś) ${ }^{19}$. W ten sposób ewangelista podkreśla, iż Piotr wziął Jezusa „dla siebie”, „ku sobie”, co polskie tłumaczenia oddają jako „na bok” ${ }^{20}$. Jeśli cały czas mamy na uwadze, iż Jezus znajduje się w drodze do Jerozolimy (por. Mk 8,27), to zachowanie Piotra zakłóca tę wędrówkę, zmieniając wyznaczoną (gr. $\delta \in \hat{\imath})$ trasę. Jezus nie może kontynuować obranej drogi, gdyż zostaje wzięty „na bok”.

Drugą czynnością, dokonywaną przez Piotra w Mk 8,32, jest „upominanie”. W przeciwieństwie do Ewangelii Mateusza, Marek nie przytacza słów Piotra. Zaznacza jedynie, iż Apostoł

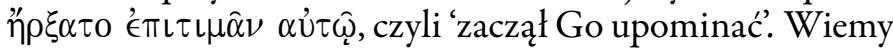
również, iż to zachowanie Piotra wywołało gniew i ostre słowa Jezusa. Warto przypatrzeć się czasownikowi étน $\tau \iota \mu \alpha \omega^{21}$. Wydaje się bowiem, iż w zachowaniu Piotra nie chodzi jedynie o zwykłe upominanie. Czasownik $\epsilon \pi \iota \tau \iota \mu \alpha ́ \omega$ w dziele Markowym pojawia się 9 razy. Trzykrotnie jego podmiotem stają się uczniowie: Piotr w naszym wersecie $(8,32)$,

20 Zob. np. Biblia Tysiąclecia czy Biblia Paulistów. Nowy Testament

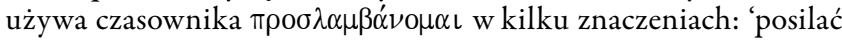
się’ (Dz 27,33.34.36), 'przygarniać' (Rz 14,1.3; 15,7; Flm 12.17), 'dobierać sobie' (Dz 17,5), a także 'zabierać ze sobą' (Dz 18,26). W kontekście naszego wersetu bierzemy pod uwagę ostatnie z podanych znaczeń. Zob. Gingrich, Shorter Lexicon, 172.

21 Podstawowe znaczenie tego czasownika to 'ganić, karcić, upominać, zgromić, strofować kogoś, robić wyrzuty' (zob. Popowski, Wielki stownik, 228). 
uczniowie zabraniający przyprowadzania dzieci do Jezusa $(10,13)$ oraz karcący niewidomego pod Jerychem $(10,48)$. Najczęściej jednak (6 razy) podmiotem €́ $\pi \iota \tau \iota \mu \alpha ́ \omega$ jest Jezus. Dwukrotnie używa tego czasownika w relacji do uczniów, i są to akurat wersety należące do naszej perykopy: raz, kiedy nakazuje uczniom milczenie $(8,30)$, i drugi raz, kiedy karci Piotra $(8,33)$. W innych przypadkach czasownik zostaje użyty podczas uciszenia burzy na jeziorze, kiedy Jezus ,zgromił wicher" $(4,39)$, oraz trzykrotnie, kiedy wyrzucał złego ducha $(1,25 ; 3,12 ; 9,25)$. Te trzy ostatnie przypadki wydają się najistotniejsze w kontekście naszej perykopy. Czasownik

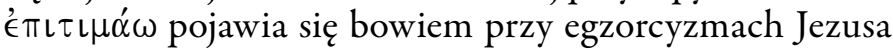
i oznacza nie tylko „upominanie”, jak to sugeruje tłumaczenie wersetu 8,32. Termin $\epsilon \pi \iota \tau \iota \mu \alpha ́ \omega$ w Ewangelii Marka znaczy coś więcej, co widać również w polskich przekładach. Biblia Tysiąclecia tłumaczy kolejno: „rozkazał mu surowo” $(1,25)$, „surowo im zabraniał” $(3,12)$ i ponownie „rozkazał surowo" $(9,25)^{22}$. Piotr więc nie tylko „zaczął upominać” Jezusa. W jego zachowaniu widać coś więcej. On „rozkazuje surowo”, „stanowczo zabrania”, „gromi” Jezusa. Co więcej, skoro czasownik '́ாı $\tau \iota \mu \alpha \dot{\alpha} \omega$ zostaje użyty w kontekście egzorcyzmów, można zaryzykować stwierdzenie, iż Piotr zaczyna traktować Jezusa, jakby był opętany przez złego ducha ${ }^{23}$. Bierze Jezusa na bok i chce dokonać nad Nim egzorcyzmu ${ }^{24}$. Do tego stopnia nie dopuszcza myśli o tym wszystkim, co ma się wydarzyć w Jerozolimie.

22 Biblia Paulistów zachowuje ten sam sens, zmieniając jedynie przysłówek „surowo” na „stanowczo”.

23 Por. Stock, Il cammino, 45. Niektórzy próbują to wytłumaczyć jedynie w sposób psychologiczny, zwracając uwagę na porywczy charakter Piotra. Np. Hendriksen: „What the others may have thought he uttered. He was the man of words and action. What they may have wanted to do he did". Hendriksen, Exposition, 328.

24 „Peter attributes Jesus' foreboding about death to a Satanic assault, and he tries to cast it out of Jesus' mind". Marcus, Mark, 614. 


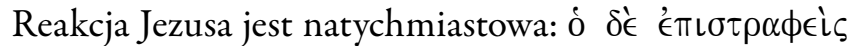

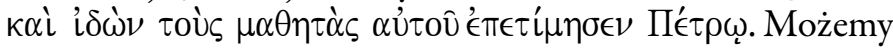
w niej zauważyć trzy czynności. Po pierwsze, Jezus odwraca się po tym, jak został przez Piotra „wzięty na bok”, czyli sprowadzony z obranej drogi do Jerozolimy. Odwrócenie się Jezusa to ponowne obranie właściwego kierunku. Nikt ani nic nie może odwieść Jezusa od drogi, którą obrał, wypełniając Boże $\delta \in \hat{l}$ (por. Mk 8,31). Po drugie, co zostało zauważone przy porównaniu synoptycznym, Jezus patrzy na swoich uczniów. Jego reakcja odnosi się zatem nie tylko do jednego z Apostołów, ale do całego grona Dwunastu. To, co się wydarzy, ma być lekcją dla wszystkich. Po trzecie, Jezus „,zgromił Piotra”. Znajdujemy tu znany nam czasownik é $\operatorname{\iota } \tau \iota \mu \alpha \dot{\alpha} \omega$. To nie Jezus, lecz Piotr ma potrzebę bycia uwolnionym od złego ducha $^{25}$. To uczniowie mają potrzebę egzorcyzmu uwalniającego ich od przeciwnika, który chce zniweczyć ich wędrówkę do Jerozolimy. Jeśli termin é $€ \iota \iota \mu \alpha \alpha^{\prime} \omega$ służy do walki ze złym duchem, to w naszej perykopie ta walka sięga zenitu. Nigdzie bowiem w Ewangelii nie ma tak częstego występowania tego czasownika. Spotykamy go w trzech następujących po sobie wersetach: Mk 8,30.32.33, a to wszystko dlatego, że jest ktoś, kto, opanowując nawet Piotra, chciałby zawrócić uczniów z obranej drogi ku Jerozolimie.

Ewangelista Marek podaje również słowa wypowiedziane

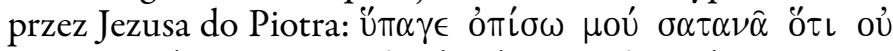

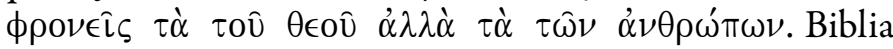
Tysiąclecia w kolejnych wydaniach tłumaczy je na język polski jako: „Zejdź mi z oczu, szatanie, bo nie myślisz po Bożemu, lecz po ludzku”. W wypowiedzi Jezusa zauważamy wyraźnie dwie części połączone ze sobą spójnikiem ötı wprowadzającym zdanie przyczynowe („Zejdź mi z oczu (...) dlatego, że...”).

25 Niektórzy komentatorzy „ograniczają” działanie Jezusa jedynie do upomnienia (ang. ,rebuke”, np. w: Collins, Mark, 407; Hendriksen, Exposition, 326), nagany (ang. „reproof”, np. w: van Iersel, Mark, 285) czy potępienia (ang. „reprove”, np. w: Hooker, Gospel, 204) bez związku z egzorcyzmem. 
Pierwszą jego część stanowi rozkaz Jezusa, drugą zaś - jego

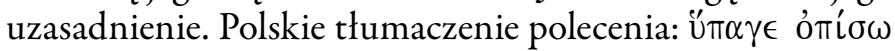
$\mu o u ́ ~ \sigma \alpha \tau \alpha \nu \alpha \hat{\alpha}$ jako: „zejdź mi z oczu, szatanie” nie do końca odpowiada oryginałowi. W rozkazie Jezusa nigdzie nie ma

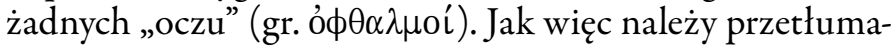
czyć te słowa będące „nerwową” reakcją Jezusa na zachowanie Piotra? Najlepiej zacząć od sensu najbardziej literalnego. Jezus mówi dosłownie: „Odejdź za Mnie, szatanie!”. Piotr, karcąc Jezusa, „wziął go na bok”, czyli niejako postawił się przed Jezusem, zaczął prowadzić Jezusa, co absolutnie nie jest zadaniem ucznia. Uczeń powinien iść za swoim mistrzem. Stąd Jezusowe: „odejdź za Mnie!”. Jezus chce przywrócić właściwy porządek w relacji uczeń-mistrz ${ }^{26}$. Wyrażenie ómí $\sigma \omega$ $\mu$ oú będzie mieć jeszcze jedno bardzo ważne znaczenie, które zostanie ukazanie w części poświęconej wymowie naszych wersetów w kontekście całej Ewangelii według św. Marka.

Piotr przez Jezusa zostaje nazwany szatanem. Trudno o mocniejsze porównanie ${ }^{27}$. Podstawowe znaczenie tego terminu, wywodzące się z języka hebrajskiego, to 'przeciwnik'28. Nawet ogólne znaczenie tego słowa pozwala nam zrozumieć, dlaczego zostało odniesione do Piotra: staje się „przeciwnikiem” Jezusa, kiedy upomina Go po pierwszej zapowiedzi męki. Nazwanie Piotra szatanem nabiera jesz-

26 Van Iersel tłumaczy ten zwrot jako: „back to the place which is his”. Van Iersel, Mark, 285. Geddert interpretuje słowa Jezusa jako: „calls him back into line”. Parafrazuje też słowa Jezusa: „Peter, I address you presently as Satan, for you speak Satan's words. But if you get behind me (opisō mou), you will return to your position as a disciple”. Geddert, Mark, 204. Hooker dopuszcza zarówno tłumaczenie: „zejdź mi z oczu”, jak i sparafrazowane: „zajmij właściwe miejsce”: "The command: «Get behind me» probably means «Get out of my sight $\gg[\ldots]$. It is possible, therefore, to understand the words here in the sense «Get back into line, Peter»". Hooker, Gospel, 206.

27 Zob. van Iersel, Mark, 285.

28 Obszerna etymologia tego terminu, której nie ma potrzeby przytaczać w niniejszym artykule, znajduje się np. w: Kardyś, Szatan, 15-19. 
cze większego znaczenia, kiedy przeanalizujemy ten termin w kontekście całego dzieła Markowego. Termin „szatan” pojawia się w nim sześć razy. Po raz pierwszy, kiedy jest mowa o kuszeniu Jezusa $(1,13)$. Osoba określona tym terminem spełnia wówczas jedno ze swoich podstawowych „zadań”: wystawia na próbę. Szatana spotykamy również w takich wersetach, jak Mk 3,23(2x).26, gdzie zostaje ukazany jako siła przeciwna wobec mocy Bożej wyrzucającej złe duchy. Wszystkie te znaczenia i zadania szatana są niemal oczywiste. Na szczególniejszą uwagę zasługuje jeszcze jeden werset z Markowej Ewangelii, w którym spotykamy szatana. To Mk 4,15, należący do dłuższej perykopy 4,13-20, będącej wyjaśnieniem przypowieści o siewcy. Jezus mówi o różnych kategoriach ludzi, do których kierowane jest Słowo Boże. Do pierwszej z nich należą „„i, [którzy są] na drodze” (gr. $\pi \alpha \rho \grave{\alpha}$

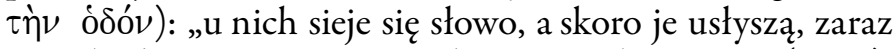
przychodzi szatan i porywa słowo w nich zasiane" (w. 15). Szatan jest zatem tym, który porywa słowo. Co więcej, porywa słowo tym, którzy są na drodze. Uczniowie z naszej

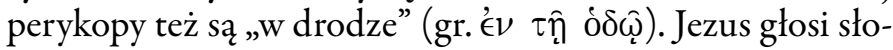
wo o swoim odrzuceniu, męce, śmierci i zmartwychwstaniu. Piotr daje sobie to słowo porwać, nie chce o nim słyszeć. Co więcej, „,bierze Jezusa na bok”, karci Go, aby inni uczniowie też tego słowa już więcej nie słyszeli. Po deklaracji: „Ty jesteś Mesjasz" $(8,29)$ szybko przyjmuje rolę szatana porywającego słowo tym, którzy byli „w drodze” do Jerozolimy.

Jezusowe skarcenie: „odejdź za Mnie, szatanie”, znajduje swe uzasadnienie w dalszej części wprowadzonej spójnikiem ő $\iota$. Jezus uzasadnia potrzebę „egzorcyzmowania” Piotra:

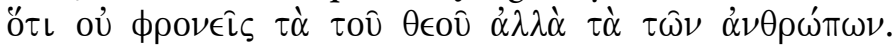
Polskie tłumaczenie BT: „bo nie myślisz po Bożemu, lecz po ludzku"29 oddaje tekst grecki niemal dosłownie, co akurat w tym miejscu nie wydaje się zbyt poprawne. Czytelnik

29 Prawie identycznie tłumaczy również Biblia Paulistów, zmieniając jedynie spójnik lecz na ale. 
polskiego tłumaczenia otrzymuje bowiem sugestię, iż błąd Piotra polega jedynie na jego błędnym rozumowaniu ${ }^{30}$. Czy Jezus jednak karciłby Piotra w tak ostrych słowach, gdyby tylko chodziło o jakąś filozofię czy sposób myślenia?

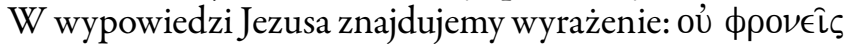

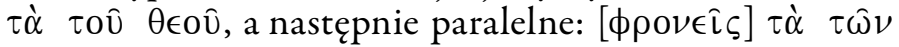
$\dot{\alpha} \nu \theta \rho \omega ́ \pi \omega \nu$. Pojawia się tu zatem następująca konstrukcja:

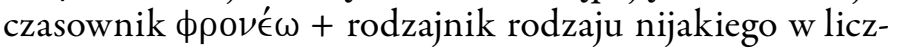
bie mnogiej $(\tau \alpha \dot{)})+$ rzeczownik w dopełniaczu ( oraz $\tau \hat{\omega} \nu \alpha \dot{\alpha} \nu \rho \omega \dot{\pi} \pi \omega \nu)$. Taka konstrukcja nie jest niczym nowym w języku greckim. Jak pokazuje w swoim artykule G. Wheaton ${ }^{31}$, spotykamy ją dość często w klasycznej literaturze greckiej, szczególnie często w tekstach narracyjnych, opisujących wydarzenia wojenne. Zarówno literatura z V-IV wieku przed Chrystusem (Herodot, Demostenes, Arystofanes), jak i z okresu III-I wieku przed Chrystusem (Diodor Sycylijski, Dionizjusz z Halikarnasu), I-II wieku po Chrystusie (Józef Flawiusz, Plutarch) czy wreszcie III wieku po Chrystusie (Kasjusz Dion) wykazuje doskonałą znajomość powyższej konstrukcji. W żadnym z omówionych przez Wheatona przypadków nie chodzi jedynie o sposób myślenia czy filozofię. W kontekście militarnym konstrukcja zostaje użyta wówczas, gdy mowa jest o przymierzu lub połączeniu sit, gdy trzeba określić tych, którzy są sprzymierzeńcami lub wrogami. Jej podstawowe znaczenie nie odnosi się do filo-

30 W takim kierunku idą też niektóre komentarze do Ewangelii według św. Marka, skupiając się na błędnym myśleniu Piotra. Np. Collins sugeruje: „Peter does not set his mind on the affairs of God” (Collins, Mark, 406), Geddert interpretuje w kluczu "divine thoughts” oraz „human thoughts” (Geddert, Mark, 204), Hendriksen: „you are looking at things not from God's point of view but from men's" (Hendriksen, Exposition, 326), Hooker: „thinking in men's way, not God's" (Hooker, Gospel, 206). Również Mascilongo w swojej monografii, w której kilka stron dedykuje wersetom 8,31-33, podaje tłumaczenie Jezusowej nagany jako: „tu non pensi secondo Dio, ma secondo gli uomini” (Mascilongo, „Ma voi, chi dite”, 287).

31 Wheaton, „Thinking”, 42-56. 
zofii czy sposobu myślenia, lecz do wyrażenia poświęcenia, zobowiązania i lojalności wobec kogoś. Wheaton definiuje ją jako wierność danej osobie, grupie, partii lub koncepcji (ang. , ,allegiance to an individual, group, party or concept") ${ }^{32}$.

W kontekście biblijnym mogą nas zainteresować szczególnie dwa miejsca ze Starego Testamentu, w których występuje podobna konstrukcja. Jedno z nich to Est 8,12b. W pierwszym zdaniu dekretu króla Artakserksesa, rehabilitującego Żydów, znajdujemy słowa: „Wielki król Artakserkses przesyła pozdrowienia stu dwudziestu siedmiu państwom od Indii aż po Etiopię, zwierzchnikom krain i tym, którzy są z nami

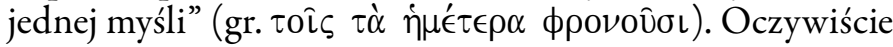
perski król nie pisze tego listu, by wymieniać się filozoficznymi poglądami czy też debatować o sposobach myślenia. Ci, „którzy są z nami jednej myśli”, to ci, „którzy są po naszej stronie" w znaczeniu militarnym i politycznym.

Drugie miejsce z Septuaginty, gdzie spotykamy podobną konstrukcję, to 1 Mch 10,20. Król Aleksander Epifanes i król Demetriusz zabiegają o sojusz z Jonatanem. Demetrisz w tej rywalizacji przegrywa, gdyż wcześniej Aleksander nadaje Jonatanowi tytuł arcykapłana, zwracając się do niego słowami: „ustanawiamy cię dzisiaj arcykapłanem twego narodu, nadajemy ci tytuł królewskiego przyjaciela [...]. Trzymaj naszą

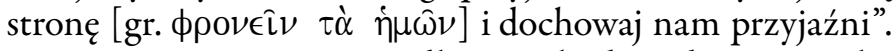
Oczywiście i w tym przypadku nie chodzi jedynie o myślenie, ale o militarne i polityczne połączenie sił. Jonatan ma „trzymać stronę” Aleksandra przeciwko Demetriuszowi ${ }^{33}$.

Wracając do naszego wersetu z Ewangelii Marka (Mk 8,33), Jezus nie czyni wyrzutu Piotrowi jedynie z powodu jego błędnego myślenia. Tłumaczenie: „nie myślisz po Bożemu, lecz po ludzku" należałoby rozumieć w kontekście napięcia, a nawet walki pomiędzy ludźmi a Bogiem i należałoby rozumieć jako: „stoisz nie po stronie Boga, lecz po stronie ludzi”.

32 Wheaton, „Thinking”, 45.

33 Zob. Wheaton, "Thinking”, 50. 
Często w Ewangelii Marka ludzie ukazani zostają w pewnej opozycji wobec Boga (np. Mk 7,7-9; 10,27; 12,14). Interpretację w tym kierunku zdaje się sugerować van Iersel w swym komentarzu, zwracając uwagę, iż kiedy Piotr wziął Jezusa na bok, nawet fizycznie stał naprzeciw Niego, podczas gdy jedenastu pozostałych uczniów znajdowało się za Jezusem ${ }^{34}$. Piotr pod Cezareą Filipową zajął pozycję naprzeciw Mesjasza, po stronie ludzi, a w konsekwencji po stronie szatana ${ }^{35}$. To musi spotkać się z ostrą reakcją Jezusa.

\section{ZnACZENIE MK 8,31-33 w KONTEKŚCie CAŁEJ EWANGELII}

Bezpośrednim kontekstem napięcia między Jezusem a Piotrem jest pierwsza mowa Jezusa o swojej męce i zmartwychwstaniu (Mk 8,31). Jezus otwarcie zapowiada, że nie jest jakimkolwiek Mesjaszem, ale ukrzyżowanym i zmartwychwstałym, i właśnie takiego Mesjasza mają zaakceptować uczniowie. Jezus wymaga od nich bezwarunkowego pójścia za sobą, nawet wówczas, gdy droga prowadzi do Jerozolimy.

Zachowanie Piotra pokazuje, jak trudno zaakceptować uczniowi cierpienie i śmierć Syna Człowieczego. Apostoł, który odczytuje w Jezusie kogoś więcej niż tylko Jana Chrzciciela, Eliasza czy jednego z proroków, nie jest w stanie zaakceptować celu drogi do Jerozolimy. Porywające, pełne mocy naucza-

34 Zob. van Iersel, Mark, 285. Szkoda, że w tłumaczeniu tego wersetu koncentruje się jednak bardziej na sposobie myślenia: „You are setting your mind not on the divine things but on the human things". Van Iersel, Mark, 281.

35 „When the human way opposes God's way, it is demonic”. Geddert, Mark, 204. Hendriksen sugeruje, iż mocne słowa Jezusa nie odnoszą się do Piotra. Jezus jedynie fizycznie zwraca się do Piotra, ale mówi do szatana: „in speaking to Peter, Jesus is actually addresing Satan”. Hendriksen, Exposition, 328. Trudno zgodzić się z takim tłumacze-

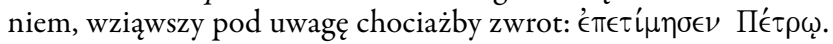


nie, uzdrowienia, wypędzanie złych duchów to wszystko jak najbardziej wpisuje się w Piotrowe wyobrażenia o mesjaszu. Kiedy jednak na horyzoncie ma się pojawić krzyż, Apostoł zachowuje się jak opętany, co musi spotkać się z ostrą reakcją ze strony Jezusa.

Czy ta reakcja Jezusa polega na odrzuceniu Piotra, rozczarowaniu się pierwszym z Apostołów? Absolutnie nie. Chociaż Piotr przez chwilę staje po stronie ludzi, przeciwko Temu, którego nazwał Mesjaszem, to jednak otrzymane od Jezusa upomnienie: „odejdź za Mnie”, ma przede wszystkim cel terapeutyczny i dydaktyczny. Widać to szczególnie wówczas, gdy odczytamy scenę spod Cezarei Filipowej w kontekście całej Ewangelii według św. Marka. Kluczem stają się tutaj słowa:

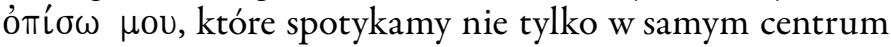
Ewangelii $(8,33)$ ale również na jej początku $(1,17)$, gdzie wyrażenie to pojawia się w kontekście powołania pierwszych uczniów. Jezus, przechodząc obok Jeziora Galilejskiego, widzi Szymona oraz Andrzeja i kieruje do nich wezwanie: „Pójdźcie za Mną" ( $\delta \in \hat{v} \tau \epsilon ~ o ́ \pi i ́ \sigma \omega \mu$ ov). Efektem tego wezwania jest natychmiastowa reakcja powołanych: „porzuciwszy sieci, po-

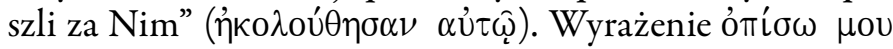
stanowi zatem istotę powołania Piotra: ma iść za Jezusem.

Ostra reakcja Jezusa pod adresem Piotra w Mk 8,33 nie ma zatem na celu odrzucenia Apostoła, co mogłoby sugerować polskie tłumaczenie: „zejdź mi z oczu”. Chociaż Piotr staje po stronie ludzi, czy nawet szatana, który chce porwać Słowo, chociaż zachowuje się w sposób niegodny ucznia, to jednak nie zostaje „skreślony” z listy Dwunastu. Jezus $\mathrm{w}$ mocnych słowach, graniczących nawet $\mathrm{z}$ egzorcyzmem (czasownik $\epsilon \pi \iota \tau \iota \mu \alpha \dot{\alpha} \omega)$, ponownie Piotra powołuje ${ }^{36}$. Pierwszy raz powołał go nad Jeziorem Galilejskim i było to wezwanie do „pójścia za” Jezusem. Teraz powołuje go ponownie i jest

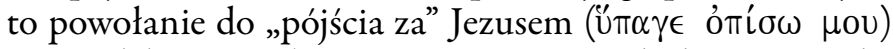
w sposób bezwarunkowy, nawet wówczas, gdy droga prowadzi 
do Jerozolimy. Po raz trzeci Apostoł zostanie powołany na końcu Ewangelii, już po zmartwychwstaniu Jezusa. Niewiasty przy grobie otrzymają od młodzieńca w białych szatach polecenie, które mają przekazać uczniom i nieprzypadkowo wspomnianemu z imienia Piotrowi: „Podąża przed wami

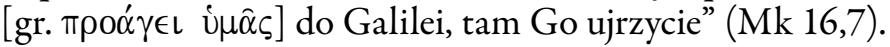

\section{BIBLIOGRAFIA}

Aland K. (red.), Synopsis quattuor Evangeliorum. Locis parallelis evangeliorum apocryphorum et partum adhibitis edidit Kurt Aland (Stuttgart: Deutsche Bibelgesellschaft $\left.{ }^{15} 2005\right)$.

Best E., Following Jesus. Discipleship in the Gospel of Mark (JSNT 4; Sheffield: JSOT Press 1981).

Collins A.Y., Mark. A Commentary (Minneapolis, MN: Fortress Press, 2007).

Dinkler M.B., „Suffering, Misunderstanding, and Suffering Misunderstanding: The Markan Misunderstanding Motif as a Form of Jesus' Suffering", Journal for the Study of the New Testament 38 (2016) 316-338.

Eckey W., Das Markusevangelium. Orientierung am Weg Jesu.

Ein Kommentar (Neukirchen: Neukirchener Verlag 1998).

Egger W., Metodologia del Nuovo Testamento. Introduzione allo studio scientifico del Nuovo Testamento (Bologna: Edizioni Dehoniane 2002).

Ernst J., Il vangelo secondo Marco (Brescia: Morcelliana 1991). France R.T., The Gospel of Mark. A Commentary on the Greek Text (The New International Greek Testament Commentary; Grand Rapids, MI - Cambridge: Paternoster Press 2002). Geddert T.J., Mark. Believers Church Bible Commentary (Scottdale, PA - Waterloo: Herald Press 2001).

Gingrich F.W., Shorter Lexicon of the Greek New Testament. Second Edition Revised by Frederick W. Danker (Chicago, IL: The University of Chicago Press ${ }^{2} 1983$ ). 
Gnilka J., Das Evangelium nach Markus. Evangelisch-katholischer Kommentar zum Neuen Testament (Neukirchen: Neukirchener Verlag 1979).

Van Iersel B.M.F., Mark. A Reader-Response Commentary (London - New York, NY: T\&T Clark International 2004).

Haręzga S., „Biblijna parrēsia i jej aktualność w świetle encykliki Redemptoris missio", Ateneum Kaptańskie 118 (1992) 293-306. Haręzga S., Jezus i Jego uczniowie. Model chrześcijańskiej formacji w Ewangelii wedtug św. Marka (Lublin: Wydawnictwo KUL 2007).

Hendriksen W., Exposition of the Gospel according to Mark. New Testament Commentary (Grand Rapids, MI: Bakerbooks 2002). Hooker M.D., The Gospel according to St Mark. Black's New Testament Commentary (London: Hendrickson Publishers 2006).

Kardyś W., Szatan w Starym Testamencie oraz w judaizmie Drugiej Świątyni. Studium z historii tradycji (Studia Biblica Lublinenesia 12; Lublin: Wydawnictwo KUL 2015).

Légasse S., Marco (Roma: Borla 2000).

Maggioni B., Il racconto di Marco (Cittá di Castello: Cittadella Editrice 1975).

Malina A., Ewangelia wedtug świętego Marka. Rozdziaty 1,1-8,26. Wstę, przektad z oryginatu, komentarz (Nowy Komentarz Biblijny 2/1; Częstochowa: Edycja Świętego Pawła 2013).

Marcus J., Mark 8-16. A New Translation with Introduction and Commentary (The Anchor Yale Bible 27 A; New Haven, CT - London: Yale University Press 2009).

Mascilongo P., „Ma voi, chi dite che io sia?”. Analisi narrativa dell'identità di Gesù e del cammino dei discepoli nel Vangelo secondo Marco, alla luce della "Confessione di Pietro" (Mc 8,2730) (AnBib 192; Roma: Gregorian and Biblical Press 2011). Piwowar A., Sktadnia jezyka greckiego Nowego Testamentu (Materiały pomocnicze do wykładów z biblistyki 13; Lublin: Wydawnictwo KUL ${ }^{2} 2017$ ).

Popowski R., Wielki stownik grecko-polski Nowego Testamentu - wydanie zpetna wokalizacja greckich haset, kluczem polsko- 
-greckim oraz indeksem form czasownikowych (Warszawa: Vocatio 1995).

Stock K., Il cammino di Gesù verso Gerusalemme (Roma: Editrice Pontificio Istituto Biblico 2008).

Stock K., Marco. Commento contestuale al secondo Vangelo (Roma: Apostolato della Preghiera ${ }^{2} 2010$ ).

Taylor V., The Gospel according to St. Mark. Greek Text with Introduction, Notes and Indexes (London: Macmillan ${ }^{2} 1966$ ). Wheaton G., „Thinking the Things of God? The Translation and Meaning of Mark 8:33c", Novum Testamentum 57 (2015) 42-56. Zolondek M.V., ,The Authenticity of the First Passion Prediction and the Origin of Mark 8.31-33", Journal for the Study of the Historical Jesus 8 (2010) 237-253.

Ks. Tomasz BĄK, prezbiter diecezji rzeszowskiej, adiunkt Katedry Filologii Biblijnej i Literatury Międzytestamentalnej Instytutu Nauk Biblijnych KUL. Uzyskał licencjat nauk biblijnych Papieskiego Instytutu Biblijnego w Rzymie (2009), a następnie licencjat (2011) i doktorat nauk orientalnych (2014) na Wydziale Orientalnym „Biblicum” w Rzymie. Jego badania koncentrują się na Ewangeliach synoptycznych oraz filologii i literaturze koptyjskiej. 